\title{
Do Farmers' Asset Values Correlate with Land Quality?
}

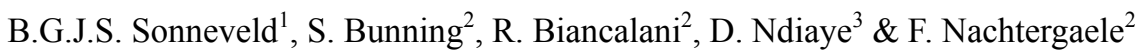 \\ ${ }^{1}$ Centre for World Food Studies of the VU University Amsterdam, The Netherlands \\ ${ }^{2}$ Food and Agriculture Organization of the United Nations, Rome, Italy \\ ${ }^{3}$ Centre de Suivi Ecologique, Dakar, Senegal \\ Correspondence: B.G.J.S. Sonneveld, SOW-VU, Vrije Universiteit, De Boelelaan 1105, 1081 HV Amsterdam, \\ The Netherlands. Tel: 31-20-598-9321; 31-20-598-9304. E-mail: b.g.j.s.sonneveld@sow.vu.nl
}

Received: October 9, 2015 Accepted: December 7, 2015 Online Published: January 26, 2016

doi:10.5539/jsd.v9n1p268

URL: http://dx.doi.org/10.5539/jsd.v9n1p268

\begin{abstract}
This paper investigates if farmers' asset values have a predictive power to asses land quality. A rich sustainable livelihood literature describes small farmers' biophysical and socio-economic environment through asset values, which closely adheres to the required information for an integrated quality appraisal of the natural resource base. For our analysis we use an in-depth survey held among 50 famers' households in three rural areas of Senegal. Farmers gave scores for their livelihood assets (human, physical, natural, financial and social) and judgments on the state and trend of the quality of their natural resource base (crop land, rangeland, forest and water resources). As our observational data are dominated by unobserved heterogeneity, we refrain from causal statistical analysis and seek associative patterns between asset values and state and trend of natural resource quality using data visualization techniques and descriptive statistics. We compare categorical data on state and trend of land qualities with asset value classes in a frequency distributions evaluation (Chi-square) and with continuous asset value scores in an analysis of variance (ANOVA). For state of forest we found consistent but counterintuitive differences for various asset values with higher asset values for 'degraded' classes and lower values for 'good' quality of the forests. There is some evidence that trend of forest quality can be derived from asset value scores which were in agreement with our premise of lower scores for low quality and higher scores for better quality. Yet, overall we have to conclude that asset values do not correlate straightforward and unequivocally with state and trend of natural resource quality.
\end{abstract}

Keywords: Senegal, natural resource quality, asset value, farmers

\section{Introduction}

Degradation of the natural resource base constitutes a serious impediment to meet the increasing demand for food commodities of a mounting and more affluent global population. Especially farmers in development countries with restricted access to capital and inputs to compensate detrimental land degradation effects are hit hard by a decreasing productivity of the natural resource base (Pingali, Schneider \& Zurek, 2014).

Senegal is a particular point in case. Sonneveld, Keyzer, Zikhali \& Merbis (2010) (Note 1) showed that 34 per cent of the national territory and 58 per cent of the agricultural area is affected by land degradation and now seriously impairs the quality of eco-system services and food production. The same study showed that an additional 26 per cent of the total land area and 40 per cent of the agricultural area faces an expansion of the degradation. With a staggering population growth of 2.9 per cent in the period 2010-2015 (UNData, accessed 2014) and a prevailing 19 per cent of chronic malnutrition under children (DHS, 2013), Senegal is confronted with a huge challenge to secure the food production for its future population and protect the long-term productive capacity of its natural resource base.

The Senegalese government has recognized the severity of these problems (Declaration of Abuja; IFDC, 2006; Senegal Emergent Plan; ADB, 2014) and the calls for a warning system that timely identifies conditions under which land degradation occurs are, therefore, justified and demands a proper follow-up from the research community. Yet, planning of policy interventions seems to be constrained by a clear identification of conditions and land user profiles that can be related to the hazard of natural resource degradation. Profiling of potential victims of degradation processes is also the main incentive to shift the research from biophysically process-based models (e.g. Quine et al., 1997; Hairsine and Rose, 1992; Gamvroudisa, Nikolaidisa, Tzorakib, Papadoulakisc, 
Karalemasc, 2015) that follow physical flows of degradation in detail to a more integrated analysis that includes biophysical as well as socio-economic and institutional conditions (e.g. Vu, Frossard, Vlek, 2014; Nkonya and Weston, 2015). There are basically two reasons for this. First, physically based models designed in a laboratory and in small field plots could not cope with the variability of field conditions at larger scales that are required for policy making at the higher levels (Nearing and Hairsine 2011). Hence, these models required a strong site specific calibration program and local expert knowledge of the terrain which, of course, excludes their universal use in places that could not be visited (Breshears, Whicker, Johansen, \& Pinder, 2003). A second reason is that degradation of natural resources is by definition evoked by an interaction between environmental conditions and human behavior. Hence, causal relationships that are relevant for defining land conservation policies require knowledge of the biophysical environment as well as of land users and related institutions that require coordinated activities beyond the individual level. Hence, most analytical studies on natural resource degradation follow integrated statistical approaches where information collected on natural environmental factors and socio-economic conditions of custodians are used to identify the significance of causal relationships or associative patterns that can explain the state of land quality (e.g. Pender, Nkonya, Jagger, Sserunkuuma, \& Ssali, 2004; Firew, 2014).

This paper follows the latter approach and seeks the possibility to relate asset values derived from the sustainable livelihood approach (Chambers and Conway, 1992; Scoones, 1998) to the hazard of natural resource degradation. Using approaches described in Carney (1998) this study adopts the use of five asset values that are essential for the pursuit of livelihood strategies that are related to land quality:

- Natural capital. Natural resource stocks and environmental services.

- Financial capital. Capital base, access to credit.

- Human capital. Skills, knowledge, ability to labor and physical capability.

- Social capital. Resources for coordinated actions.

- Physical capital. Basic infrastructure and production equipment.

These asset values provide a comprehensive dynamic overview of farming systems, monitor development and changes in their levels over time (e.g. Chen, et al., 2013; Katerberg et al., 2012) so as to identify timely the constraints for sustainable development and express the concerns over employment, poverty reduction, security, well-being and capability as well as quality of the natural resource base.

We will confront the value of these assets with qualitative assessments on the state and trends in degradation for various natural resources that are managed by the rural population in Senegal. Specifically, farmers were asked to value assets with a score between 0 (low) and 10 (high) and indicate for four natural resources (crop land, rangeland, forest and water) the quality of their current state as 'low', 'moderate' and 'high' and the quality of changes over time (trend) as 'rapidly decreasing', 'decreasing', 'stable', 'improving' and 'rapidly improving'. For our study we use data that were collected under the FAO/UNEP sponsored Land Degradation in Dryland Areas (LADA) project. Guidelines on the Local Level Assessment of Land Degradation and Sustainable Land Management were provided by Bunning, McDonagh, Rioux, \& Woodfine, 2011. With this study we aim to support decision makers into prioritizing policy interventions that target specific assets so as to improve the quality and productivity of the natural resource base.

The paper proceeds as follows. Section 2 describes data and methodology used in this study. Section 3 discusses the relation between asset values and rate and state of resource quality for crop land, rangeland, forest and water resources. Section 4 concludes.

\section{Data and Methods}

A team of field experts conducted a detailed local assessment on natural resource quality and asset values. The assessment consisted of focus group discussions at village level, household surveys among farmer families and a soil and vegetation inventory. The methodologies for these local assessments are described in (Mcdonagh et al., 2010). Here we present a brief summary of the guiding principles for this data collection exercise and its application in Senegal.

\subsection{Sampling Strategy}

Three Geographic Assessment Areas (Note 2) (GAA) were selected that were representative for major land uses, biophysical variability and degree of natural resource degradation in Senegal. Based on interviews and reconnaissance surveys one to three transects were defined that followed the diversity of prevailing biophysical and land use characteristics in the GAAs. Along these transects two to three representative study areas were 
selected where one to four representative villages where visited for focus group discussion with key informants of the community (one per village) and household surveys (four to six per village). The distribution of the selection of households over the wealth classes (poor, medium, better-off) followed the prevailing wealth distribution of the village population. Descriptive narratives of selected GAAs, transects, study areas, villages and sites are found in the reports CSE (2009a-e), a short description of the three GAAs is given below.

Niayes is a coastal area with rainfall varying from $300-400 \mathrm{~mm}$ per annum concentrated in the months of August and September. 'Living' white dunes near the coast are followed by semi-fixed yellow dunes more inland. Humid depressions with fertile soils ('niayes') are a regular occurrence. At the boundary of these depressions typically oil palm and coconut are found. Main land use is horticulture in the 'niayes', but livestock and forestry are also a source of income.

Nioro du Rip has a mean annual rainfall of about $700 \mathrm{~mm}$. Approximately $85 \%$ of the rainfall occurs in the months July, August and September. Terrain is relatively flat and soils vary in fertility levels. Main land use type is rainfed agriculture with groundnuts, millet, maize and sorghum as crops. Where water availability permits, horticulture is also practiced. Second most important land use is rearing of livestock in a sedentary extensive manner.

Zone sylvopastoral is located in the North of Senegal with mean annual rainfall of about $400 \mathrm{~mm}, 90$ per cent of which falls in July, August and September. Soils are mainly formed in sedimentary formations with flat topography and varying in texture from sandy to clayey. The main activity is keeping livestock in an extensive manner; in the rainy season there is some arable farming. Some forestry activities are conducted like collection of fruit, fuel wood, timber and pole wood. In total 50 households were interviewed. The number of households and their location within each GAA is presented in

Table 1.

Table 1. Number of households by GAA, transect and village

\begin{tabular}{lrrr}
\hline \multirow{2}{*}{ GAA } & Transect & Village & $\begin{array}{c}\text { Number of } \\
\text { farmers }\end{array}$ \\
\hline \multirow{2}{*}{ Niayes } & Lompoul-Thioucougne & Lompoul sur Mer & 4 \\
& Mabouye-Khonkh Yoye & Mabouye & 3 \\
& & khonkh_yoye & 3 \\
Nioro_du_Rip & Keur-Yoro-Khoudia & Keur Massamba Codou & 4 \\
& & Thiambène Walo & 3 \\
& & Keur Tapha-Koutango & 4 \\
& & Keur_Amady_Nguenar & 3 \\
& & Thiwalo-Keur Aly Mbath & 4 \\
& & Diabal & 3 \\
Zone_sylvopast & Diabal-Niakha & Niakha & 3 \\
& Diagaly-A3 & Diagaly & 6 \\
& Touba_NF_A3 & Katma & 2 \\
& & Touba_Ndar_Fall & 4 \\
\hline
\end{tabular}

\subsection{Survey Data}

The survey collected information on a wide inventory of various subjects related to natural resource quality, socio-economic conditions of the household, and the institutional environment that are described in McDonagh et al. (2010). Here we concentrate on the information that was collected by the farmers on asset values and state and trend of natural resource degradation. Concerning asset values, farmers were asked to give a score (in the range of 0-10) for each of the five assets taking into consideration the topics that are listed in 
Furthermore, each farmer was asked to indicate the quality and trends of land degradation for crop land areas, rangeland, forests and water sources with the descriptive terms that are presented in

Table 3 and Table 4, respectively

\subsection{Statistical Analysis}

We practice two descriptive statistical techniques. First, Pearson's Chi-square tests the null hypothesis whether paired observations of categorical asset classes and qualitative state and trend of land quality classes are independent of each other, which means that distribution of data is due to chance and asset value classes will have no relation to state and trend of natural resource degradation. We, therefore, report on expected distribution under the null hypothesis so as to assess if patterns deviate significantly from observed values. The expected value within each cell is the product of row total and column total divided by overall sample (Preacher, 2001). Second, we test the variability between group means of asset value scores and compare these with results that are expected from chance alone. Our unbalanced observations for the qualitative state and trend of land quality assessment demands the use of a Generalized Linear Model (GLM) approach which takes into account the size of the data set to assess variance as a measure of variability. The ratio of the asset value mean square and the error mean square (deviations of data around the group means) is the well-known F-ratio. The F distribution represents the range and likelihood of all possible F-ratios under the null hypothesis (i.e. asset values are identical for all land quality classes). The threshold probability was set at 0.1 and 0.05 .

Table 2.

Furthermore, each farmer was asked to indicate the quality and trends of land degradation for crop land areas, rangeland, forests and water sources with the descriptive terms that are presented in

Table 3 and Table 4, respectively

\subsection{Statistical Analysis}

We practice two descriptive statistical techniques. First, Pearson's Chi-square tests the null hypothesis whether paired observations of categorical asset classes and qualitative state and trend of land quality classes are independent of each other, which means that distribution of data is due to chance and asset value classes will have no relation to state and trend of natural resource degradation. We, therefore, report on expected distribution under the null hypothesis so as to assess if patterns deviate significantly from observed values. The expected value within each cell is the product of row total and column total divided by overall sample (Preacher, 2001). Second, we test the variability between group means of asset value scores and compare these with results that are expected from chance alone. Our unbalanced observations for the qualitative state and trend of land quality assessment demands the use of a Generalized Linear Model (GLM) approach which takes into account the size of the data set to assess variance as a measure of variability. The ratio of the asset value mean square and the error mean square (deviations of data around the group means) is the well-known $F$-ratio. The $F$ distribution represents the range and likelihood of all possible $F$-ratios under the null hypothesis (i.e. asset values are identical for all land quality classes). The threshold probability was set at 0.1 and 0.05 .

Table 2. Topics considered for asset scoring

\begin{tabular}{ll}
\hline Asset & Topic \\
\hline \multirow{2}{*}{ Physical } & Farm equipment \\
& Type of traction \\
& Motorcycle \\
\hline \multirow{2}{*}{ Financial } & Microcredit \\
& Agricultural Income \\
& Income derived from rearing \\
\hline Natural & Other income sources \\
\hline
\end{tabular}


Farm size

Land quality

Quality of drinking water (for animals)

Quality of Grazing land

Education

Household size

Number of workers

Human Know-how

Technical support

Membership of organization

Access to land

Kinship network

Food safety

Social

Access to markets

Access to health care

Access to school

Access to drinking water

Table 3. Class categories on quality of natural resources

\begin{tabular}{cc}
\hline Code & Category \\
\hline 1 & good \\
2 & Moderate \\
3 & Low/degraded \\
\hline
\end{tabular}

Table 4. Class categories trend in resource degradation

\begin{tabular}{cc}
\hline Code & Category \\
\hline 1 & improving fast \\
2 & Improving \\
3 & Stable \\
4 & Decreasing \\
5 & rapidly decreasing \\
\hline
\end{tabular}

\section{Results}

We start our analysis of household surveys by analyzing the distribution of scores for: social, human, natural, financial and physical assets in each of the three GAAs. Next, we report on state and trends in land quality for natural resources: crop land, rangeland, forest and water. Finally, we combine the asset with information on state and trend of natural resource quality. 


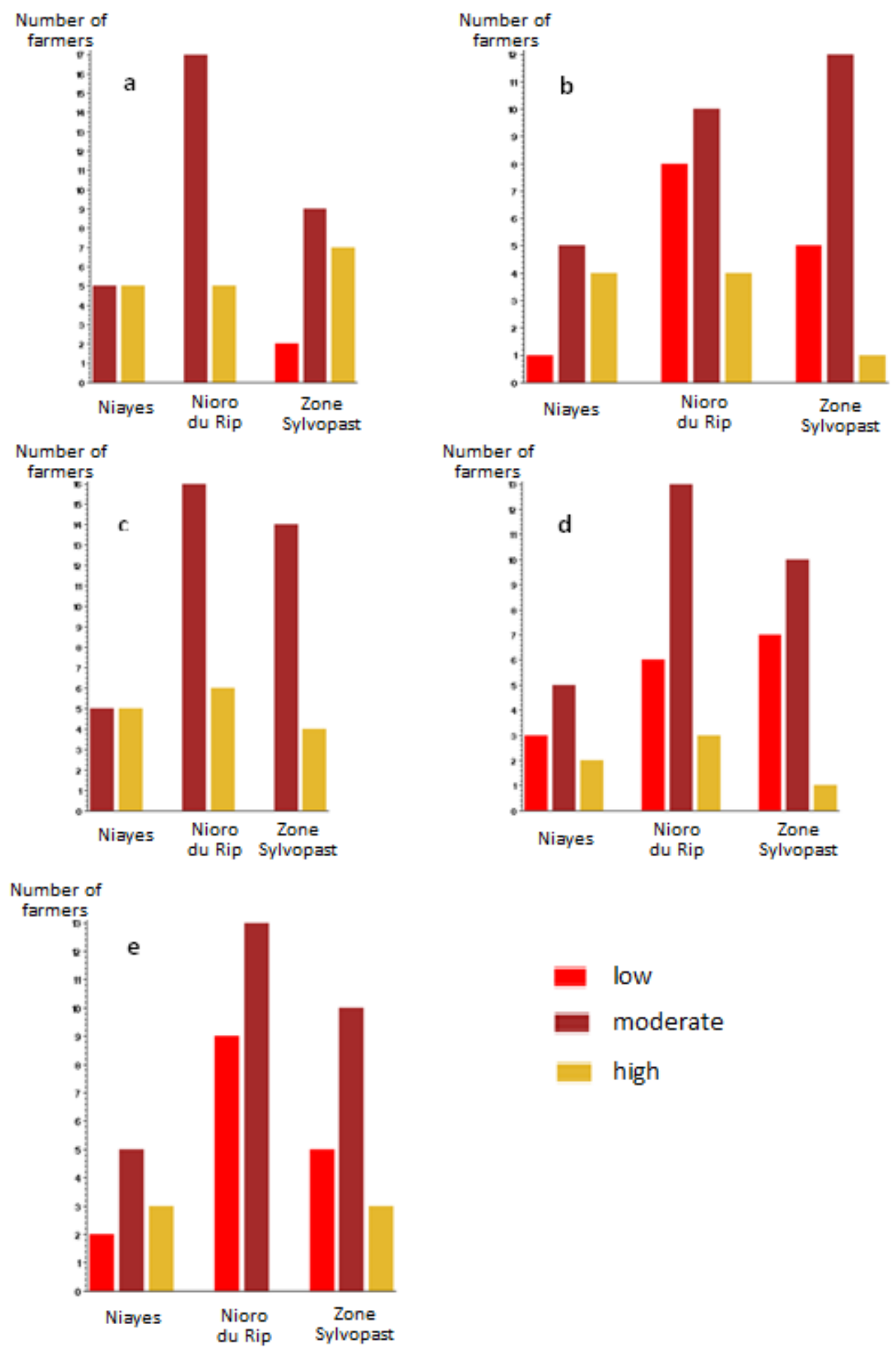

Figure 1. Frequency distribution of farmers by asset value class for each GAA: social (upper left; a ), human (upper right; b), natural (middle left; c), financial (middle right; d) and physical (lowest; e) assets

\subsection{Asset Value Scores by GAA}

For visualization and comparison the asset values were aggregated into three classes: 'low' (score 0-4), 'moderate' (5-7) and 'high' (8-10). Figure 1 shows the frequency distribution of the number of farmers by GAAs for these asset classes concerning: social, human, natural, financial and physical capital. The 'moderate' class in 
the frequency distribution is clearly dominant for all assets, followed by the 'high' asset class. 'Low' asset classes are found for human, physical and financial assets. 'Low' classes in Niayes, Nioro du Rip and Zone Sylvopastoral reported, 20, 41 and 28 per cent for physical assets; for financial assets: 30, 27 and 39 per cent and for human assets: 10, 37 and 28 per cent, respectively. The social and natural capital is considered by the majority of the farmers as 'moderate' to 'high'. The results do not show clear trends that point to different prevailing distribution patterns between GAAs. Therefore, in the following paragraphs, we analyze the state and trend of land quality for all farmers with an occasional reference to specific outcomes by GAA.
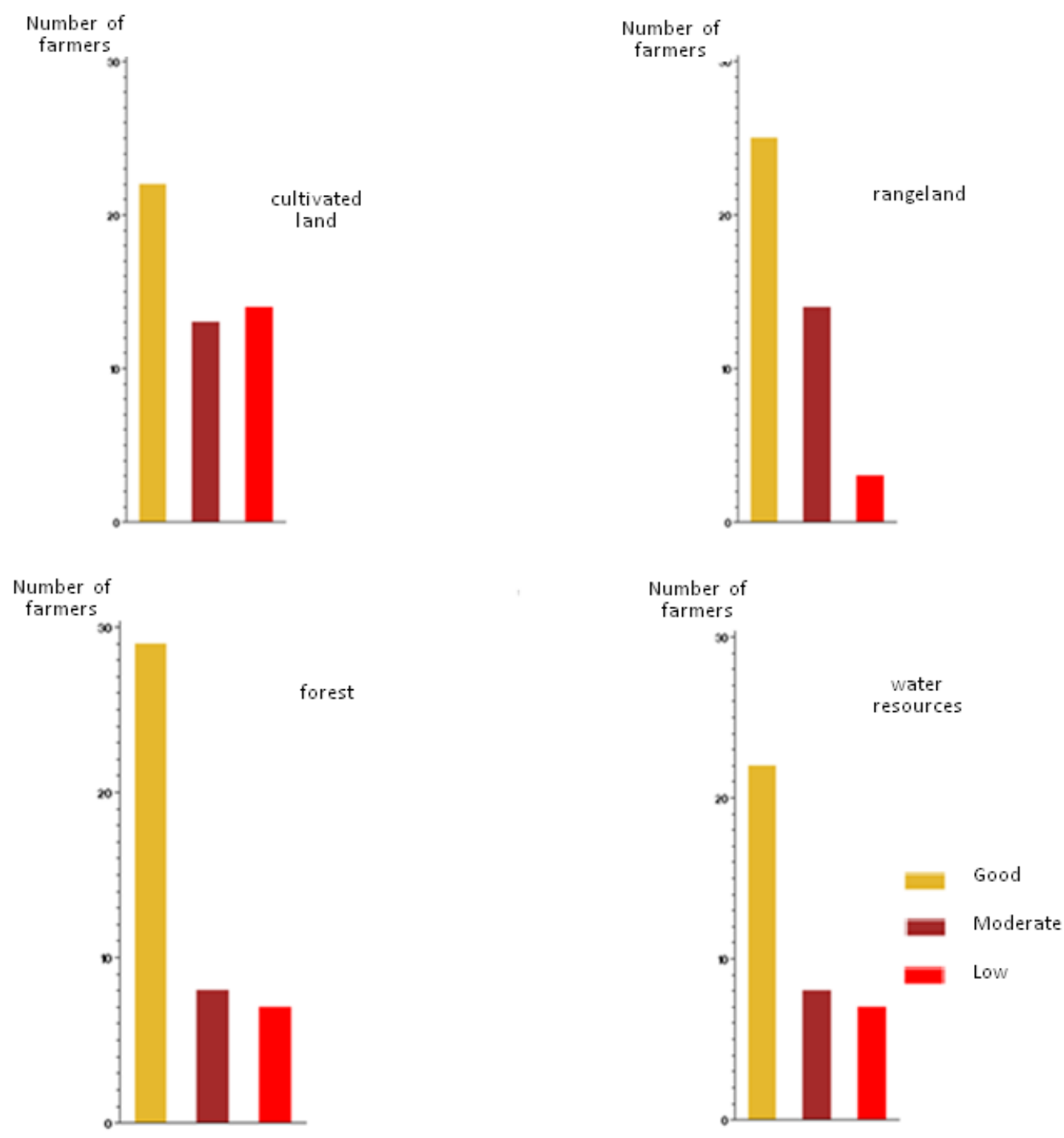

Figure 2. Frequency distribution of farmer responses on state of natural resource quality for: culitivated land (upper left), rangeland (upper right), water resources (lower left) and forest (lower right)

\subsection{State and Trend of Land Quality}

Of the 50 interviewed farmers $49,42,37$ and 44 gave valid answers on the state of land quality for, crop land, rangeland, forest and water quality, respectively. Figure 2shows the frequency distribution of farmer responses on state of the natural resource quality for crop land, rangeland, forest and water, respectively. These responses were classified as 'low', 'moderate' and 'high'. For crop land 29 per cent was reported as 'low' quality. A closer look into the data showed that the 'low' category holds for 50 per cent of the farmers in Nioro du Rip, against 11 per cent of the farmers in Niayes and Zone Sylvopastoral. The state of rangeland was considered 'moderate' (33 per cent) to 'good' (60 per cent). Only some farmers in Niayes (13 per cent) and Nioro du Rip (11 per cent) reported 'low' quality rangelands. For the Zone Sylvopastoral the rangelands were qualified as 'moderate' (38 per cent) to 'good' ( 62 per cent). The overall scores for forest quality, 60 per cent 'good', 22 per cent 'moderate', 
19 per cent 'low' and water resources 66 per cent 'good', 18 per cent 'moderate' and 16 per cent 'low' followed representative patterns for all three GAAs. Not all farmers responded or gave valid answers on the state of land quality. Of the 50 interviewed farmers $49,42,37$ and 44 gave valid answers on the state of land quality for respectively: cultivated land, rangeland, forest and water quality.

Figure 3 shows the frequency distribution of farmer responses on trends of natural resource quality that were classified as 'rapidly decreasing', 'decreasing', 'stable', 'improving' and 'rapidly improving'. The results show that an alarming 62 per cent of the farmers indicated a 'decreasing' to 'rapidly decreasing' trend for crop land. A further analysis of the responses by GAA shows that 71 per cent of the farmers in Niayes and 76 per cent of the farmers in Nioro du Rip reported decreasing trends; in the Zone Sylvopastoral this percentage was less, 36, but still substantial.

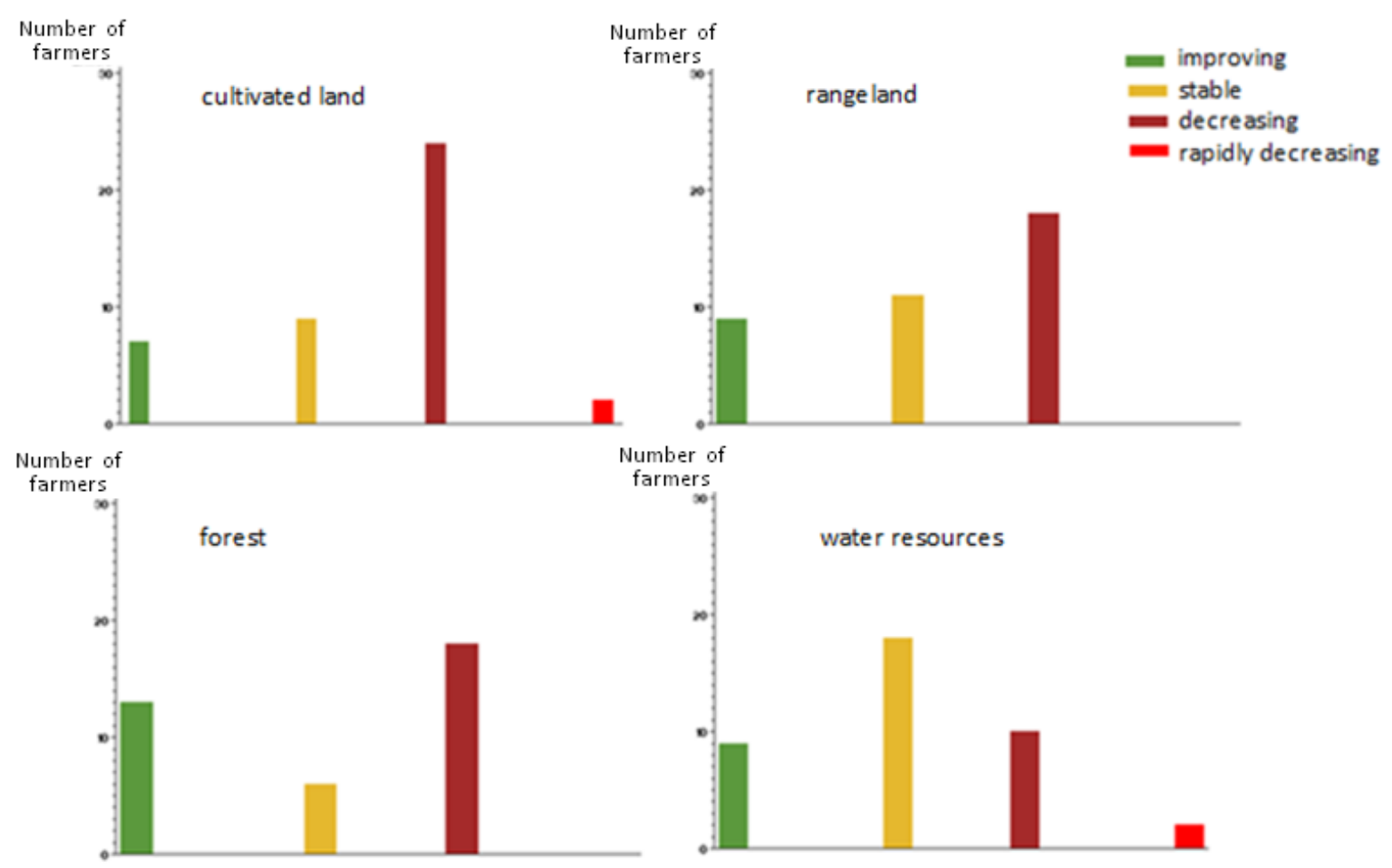

Figure 3. Frequency distribution of farmer responses on trend of land degradation for: crop land, (upper left), rangeland (upper right) forest (lower left) and water resources (lower right)

We also found similar overall decreasing trends for rangeland (47 per cent) and forest (49 per cent), whereby we note that farmers in Niayes reported a very high percentage (75 per cent) of decreasing rangeland quality, whereas farmers in Nioro du Rip and Zone Sylvopastoral reported lower decreasing rangeland trends of, respectively, 47 and 33 per cent. On the positive side we found a remarkably high percentage (71 per cent) of 'improving' forest in Niayes where Nioro du Rip and Zone Sylvopastoral recorded 29 and 23 per cent. Water resources showed in general a decreasing trend in quality for 31 per cent of the interviewed farmers. Especially,

Niayes reported high percentages of water resource degradation (50 per cent). Yet, in Nioro du Rip and Zone Sylvopastoral, respectively 71 and 79 per cent of the water resources were either stable or improving. We can conclude that, overall, the state of natural resource quality is of concern with percentages of 'low' quality varying between 7 (rangeland) and 29 (crop land) per cent. Yet, the (rapidly) decreasing land quality requires urgent attention as these percentages vary from 31 (water resources) to 62 (crop land) per cent. Furthermore, we note that in both state and trend the most affected areas are under crop land. Niayes and Nioro du Rip are the GAAs where most negative figures in state and trends of natural resource quality are reported.

\subsection{State and Trend of Natural Resource Quality by Categorized Scores of Asset Values}

In this section we analyze the association between state and trend of natural resource quality for the various asset values. Our working hypothesis is that lower asset values are indicative for natural resource degradation while 
higher classes correspond with 'good' quality. The idea of this premise is that farmers with less economic and natural endowments will have limited means to restore natural resources (e.g. Barbier, 2000; Tittonell and Giller, 2013) while richer farmers have more opportunities to maintain or increase the quality of their resource base. We conduct this analysis by comparing for the ordered state and trend classes of land quality the frequency distribution of categorical asset value classes and average differences of continuous asset value scores.

Asset value classes. Table A 1 in the Annex shows a full reporting of frequency distribution for each of the asset value classes and corresponding state of land degradation. Yet, initial runs for the Chi-square test frequently reported low cell frequencies which makes test results invalid (e.g. Hopkins and Kenneth, 1978). Hence we decided to aggregate cell frequencies over individual assets and summarize the frequency for each of the asset value classes only. 错误!未找到引用源。 reports on these results and includes the expected frequency in case that asset value classes and qualitative judgments on land quality are independent. We note that most expected values are close to observed frequencies except for forest that also shows a significant Chi-square statistic (value 22.9406, probability $<0.0001$ ) whereas Chi-square tests for other natural resources show no significant influence (values of 3.1803, 4.1390 and 5.8051 with corresponding probabilities under the zero difference hypothesis of $0.5281,0.3875$ and 0.2142 for crop land, rangeland and water resources, respectively). A closer look at the 'forest' data shows that the deviations are more or less counterintuitive as for the 'Good' state of forest we find lower frequencies as expected for the 'High' asset value class and higher frequencies for the 'Low' asset class. The opposite holds for the 'Degraded' quality state of forests where frequencies for 'High' are higher as expected and 'Low' asset classes show lower frequency than expected. We can conclude that our premise, higher asset values would indicate 'good' resource qualities and lower asset values would indicate lower ('Degraded') natural resources, has proven to be incorrect. In the majority of the cases the Chi-square test clearly shows that there is no significant difference between expected independent outcomes and observed frequency distribution.

Table A 2 in the Annex shows the frequency distribution for each of the asset values and corresponding trends of natural resource quality. For the same reason of low cell frequencies we aggregated cell frequencies over individual assets. The resulting cell frequencies including the expected frequency under independence assumption are summarized in Table 6. Cell frequencies for 'rapidly decreasing' were still at a low level and for our Chi-square analysis aggregated with the 'decreasing' class. We find that most expected values are close to the observed ones. The Chi-square statistics $(2.4395,4.7678,2.8564,4.5742$ with probabilities of $0.8752,0.3120$, 0.5821 and 0.5995 for crop land, rangeland, forest and water resources, respectively) confirm the minimal difference between observed and expected frequency distribution for all natural resources. Hence, we can conclude that the categorical asset values are not useful predictors for the trend of natural resource quality.

Table 5. Observed (and expected) frequency distribution for asset value classes and state of land quality by natural resource

\begin{tabular}{llrrrr}
\hline \multicolumn{1}{c}{ Asset value class } & Natural resource & Good & Moderate & \multicolumn{1}{c}{ Degraded } & \multicolumn{1}{c}{ Total } \\
\hline \multirow{3}{*}{ High } & crop land & $27(23.3)$ & $13(13.7)$ & $12(14.8)$ & 52 \\
& Rangeland & $24(26.7)$ & $15(15.0)$ & $6(3.2)$ & 45 \\
& forest & $19(24.3)$ & $5(8.8)$ & $17(7.7)$ & 41 \\
& water & $26(30.3)$ & $8(8.3)$ & $12(7.3)$ & 46 \\
\hline \multirow{3}{*}{ Moderate } & crop land & $61(65.1)$ & $37(38.4)$ & $47(41.4)$ & 145 \\
& rangeland & $74(73.2)$ & $43(41.0)$ & $6(8.7)$ & 123 \\
& forest & $61(62.4)$ & $30(22.7)$ & $14(19.8)$ & 105 \\
& water & $86(85.6)$ & $25(23.6)$ & $19(20.6)$ & 130 \\
\hline \multirow{3}{*}{ Low } & crop land & $22(21.5)$ & $15(12.7)$ & $11(13.7)$ & 48 \\
& rangeland & $27(25.0)$ & $12(14.0)$ & $3(3.0)$ & 42 \\
& forest & $30(23.1)$ & $5(8.4)$ & $4(7.3)$ & 39 \\
\hline Total & water & $33(29.0)$ & $7(8.0)$ & $4(7.0)$ & 44 \\
Total & crop land & 110 & 65 & 70 & 245 \\
Total & rangeland & 125 & 70 & 15 & 210 \\
& forest & 110 & 40 & 35 & 185
\end{tabular}




\begin{tabular}{|c|c|c|c|c|c|c|}
\hline Total & water & & 145 & 40 & 35 & 20 \\
\hline $\begin{array}{l}\text { Table } 6 . \text { Obs } \\
\text { resource }\end{array}$ & ed (and expected & 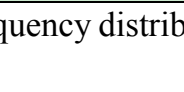 & on for as & lue classe & & \\
\hline Asset value & Natural resource & Improving & Stable & Decreasing & Rapidly decreasing & Total \\
\hline \multirow{4}{*}{ High } & crop land & $9(7.0)$ & $9(9.0)$ & $21(24.0)$ & $3(2.0)$ & 42 \\
\hline & rangeland & $5(9.7)$ & $15(11.8)$ & $21(19.4)$ & 0 & 41 \\
\hline & forest & $17(14.0)$ & $5(6.4)$ & $18(19.4)$ & 0 & 40 \\
\hline & water & $8(9.6)$ & $22(19.3)$ & $9(10.7)$ & $3(2.1)$ & 42 \\
\hline \multirow{4}{*}{ Moderate } & crop land & $21(21.1)$ & $26(27.2)$ & $75(72.5)$ & $5(6.0)$ & 127 \\
\hline & rangeland & $31(26.2)$ & $28(32.1)$ & $52(52.5)$ & 0 & 111 \\
\hline & forest & $37(37.2)$ & $16(17.1)$ & $53(51.5)$ & 0 & 106 \\
\hline & water & $28(27.0)$ & $56(54.0)$ & $28(30.0)$ & $5(6.0)$ & 117 \\
\hline \multirow{4}{*}{ Low } & crop land & $5(6.8)$ & $10(8.7)$ & $24(23.4)$ & $2(1.9)$ & 41 \\
\hline & rangeland & $9(9.0)$ & $12(11.0)$ & $17(18.0)$ & 0 & 38 \\
\hline & forest & $11(13.7)$ & $9(6.3)$ & $19(18.9)$ & 0 & 39 \\
\hline & water & $9(8.3)$ & $12(16.6)$ & $13(9.2)$ & $2(1.8)$ & 36 \\
\hline Total & crop land & 35 & 45 & 120 & 10 & 210 \\
\hline Total & rangeland & 45 & 55 & 90 & 0 & 190 \\
\hline Total & forest & 65 & 30 & 90 & 0 & 185 \\
\hline Total & water & 45 & 90 & 50 & 10 & 195 \\
\hline
\end{tabular}

\subsection{State and Trend of Natural Resource Quality by Asset Values Scores}

In this section we report on the predictive power of the mean asset value scores by asset for state and trend of natural resource quality. Table 7 shows for each natural resource the mean of the scores and their standard deviation by asset and state of natural resources. The table includes an overall score for each of the asset value classes. For crop land we find that two (human and social) out of the six reported assets the lowest value corresponds to 'degraded' state and for water resources this occurred once (natural). For rangeland and forest all asset values for 'degraded' were highest or second highest. For the 'good' state of the natural resource quality we found that for crop land three assets (physical, human and natural) had the highest value and for rangeland one (financial). Forest and water resources all reported second or third for the 'good' state of the resource. We also note that the standard deviation is relatively large which makes it less likely that differences between the mean will be significant. 
Table 7. Asset value scores, mean and standard deviation, by natural resource and state of land quality

\begin{tabular}{|c|c|c|c|c|c|c|c|c|c|}
\hline \multirow{2}{*}{ Asset } & \multirow{2}{*}{ State of land } & \multicolumn{2}{|c|}{ Crop land } & \multicolumn{2}{|c|}{ Rangeland } & \multirow{2}{*}{$\begin{array}{l}\text { Forest } \\
\text { mean }\end{array}$} & \multicolumn{3}{|c|}{ Water } \\
\hline & & mean & sdev & mean & sdev & & sdev & mean & sdev \\
\hline \multirow{3}{*}{ Physical } & degraded & 4.93 & 2.09 & 5.33 & 2.08 & 7.00 & 1.91 & 6.29 & 2.36 \\
\hline & moderate & 4.15 & 2.30 & 5.07 & 2.56 & 5.00 & 1.85 & 4.88 & 2.10 \\
\hline & good & 5.18 & 3.11 & 4.64 & 2.87 & 4.14 & 3.00 & 4.41 & 2.82 \\
\hline \multirow{3}{*}{ Financial } & degraded & 5.36 & 2.59 & 5.00 & 4.36 & 5.57 & 2.82 & 5.86 & 2.48 \\
\hline & moderate & 4.38 & 2.26 & 3.79 & 1.72 & 4.88 & 1.81 & 4.38 & 1.60 \\
\hline & good & 4.64 & 2.04 & 5.40 & 2.16 & 4.50 & 2.28 & 4.48 & 2.38 \\
\hline \multirow{3}{*}{ Human } & degraded & 4.93 & 2.20 & 7.00 & 2.65 & 5.43 & 2.57 & 6.29 & 2.14 \\
\hline & moderate & 5.00 & 2.89 & 5.43 & 2.47 & 4.63 & 2.00 & 5.25 & 2.71 \\
\hline & good & 5.14 & 2.29 & 4.36 & 1.87 & 4.64 & 2.65 & 4.48 & 2.31 \\
\hline \multirow{3}{*}{ Natural } & degraded & 6.57 & 0.94 & 7.00 & 1.00 & 7.71 & 0.49 & 6.43 & 1.13 \\
\hline & moderate & 6.54 & 1.27 & 6.29 & 1.82 & 6.00 & 1.20 & 6.63 & 1.85 \\
\hline & good & 6.77 & 1.69 & 6.72 & 1.17 & 6.55 & 1.57 & 6.59 & 1.35 \\
\hline \multirow{3}{*}{ Social } & degraded & 6.50 & 1.74 & 7.33 & 1.15 & 6.86 & 6.86 & 7.43 & 1.40 \\
\hline & moderate & 6.77 & 1.42 & 6.64 & 1.28 & 6.50 & 6.50 & 6.88 & 1.64 \\
\hline & good & 6.50 & 2.18 & 6.32 & 2.21 & 6.27 & 6.27 & 6.14 & 1.98 \\
\hline \multirow{3}{*}{ Total } & degraded & 28.29 & 6.09 & 31.67 & 8.02 & 32.57 & 8.32 & 32.29 & 5.74 \\
\hline & moderate & 26.85 & 7.49 & 27.21 & 7.99 & 27.00 & 5.61 & 28.00 & 7.35 \\
\hline & good & 28.23 & 8.35 & 27.44 & 6.95 & 26.09 & 8.02 & 26.10 & 7.57 \\
\hline
\end{tabular}

We test if asset value scores for the three natural resource quality classes are significantly different, that is, we compare scores for a) 'degraded' with 'moderate', b) 'degraded' with 'good', c) 'moderate' with 'good' and d) 'degraded' against the two other assessments.Table 8 presents the results. For crop land we do not find significant differences between asset value scores for the various states of natural resource qualities. For rangeland we find significant differences between 'moderate' and 'good' and between 'degraded' and 'good' for financial and human asset values. A closer look at Table 7 shows that for financial assets the 'moderate' score is lower as compared to the 'good', while for human asset value the score for 'degraded' is higher as compared to 'good'. For forest we find significant differences for physical, natural and total asset scores. For physical assets the scores for 'degraded' are higher as compared to 'good' and 'others' and this also holds for natural and total asset value scores. For water resources we find for human and total asset scores significant differences between higher 'degraded' scores as compared to the lower scores for the 'good' category.

Table 8. GLM-Anova results for asset value scores by asset, natural resource and state of natural resource quality

\begin{tabular}{llrrrrrrrrr}
\hline & \multicolumn{1}{c}{ Crop land } & \multicolumn{2}{c}{ Rangeland } & \multicolumn{2}{c}{ Forest } & \multicolumn{3}{c}{ Water } \\
\hline Asset & & FValue & ProbF & FValue & ProbF & FValue & ProbF & FValue & ProbF \\
\hline \multirow{3}{*}{ Physical } & degraded vs moderate & 0.575 & 0.452 & 0.023 & 0.881 & 2.164 & 0.150 & & 1.060 & 0.309 \\
& degraded vs good & 0.078 & 0.781 & 0.172 & 0.680 & 6.311 & 0.017 & $* *$ & 2.819 & 0.101 \\
& moderate vs good & 1.226 & 0.274 & 0.224 & 0.639 & 0.634 & 0.431 & 0.190 & 0.665 \\
& degraded vs others & 0.095 & 0.760 & 0.085 & 0.773 & 4.621 & 0.039 & $* *$ & 2.104 & 0.155 \\
\hline \multirow{3}{*}{ Financial } & degraded vs moderate & 1.246 & 0.270 & 0.754 & 0.390 & 0.342 & 0.563 & 1.571 & 0.217 \\
& degraded vs good & 0.869 & 0.356 & 0.089 & 0.767 & 1.151 & 0.291 & 2.041 & 0.161 \\
& moderate vs good & 0.101 & 0.752 & 4.842 & 0.034 & $* *$ & 0.156 & 0.696 & 0.014 & 0.907 \\
& degraded vs others & 1.373 & 0.247 & 0.095 & 0.760 & 0.795 & 0.379 & 2.139 & 0.151 \\
\hline
\end{tabular}




\begin{tabular}{|c|c|c|c|c|c|c|c|c|c|c|c|c|}
\hline \multirow{4}{*}{ Human } & degraded vs moderate & 0.006 & 0.940 & 1.343 & 0.254 & & 0.382 & 0.541 & & 0.720 & 0.401 & \\
\hline & degraded vs good & 0.062 & 0.804 & 4.109 & 0.050 & $* *$ & 0.528 & 0.472 & & 3.294 & 0.077 & $*$ \\
\hline & moderate vs good & 0.026 & 0.874 & 2.255 & 0.141 & & 0.000 & 0.991 & & 0.663 & 0.420 & \\
\hline & degraded vs others & 0.032 & 0.859 & 2.702 & 0.108 & & 0.544 & 0.466 & & 1.981 & 0.167 & \\
\hline \multirow{4}{*}{ Natural } & degraded vs moderate & 0.004 & 0.952 & 0.631 & 0.432 & & 5.932 & 0.020 & $* *$ & 0.071 & 0.791 & \\
\hline & degraded vs good & 0.176 & 0.677 & 0.105 & 0.747 & & 3.923 & 0.056 & $*$ & 0.070 & 0.793 & \\
\hline & moderate vs good & 0.228 & 0.635 & 0.847 & 0.363 & & 0.944 & 0.338 & & 0.005 & 0.946 & \\
\hline & degraded vs others & 0.035 & 0.852 & 0.343 & 0.562 & & 6.058 & 0.019 & $* *$ & 0.085 & 0.772 & \\
\hline \multirow{4}{*}{ Social } & degraded vs moderate & 0.138 & 0.712 & 0.325 & 0.572 & & 0.131 & 0.719 & & 0.335 & 0.566 & \\
\hline & degraded vs good & 0.000 & 1.000 & 0.759 & 0.389 & & 0.500 & 0.484 & & 2.750 & 0.105 & \\
\hline & moderate vs good & 0.167 & 0.685 & 0.258 & 0.614 & & 0.084 & 0.774 & & 0.997 & 0.324 & \\
\hline & degraded vs others & 0.050 & 0.824 & 0.555 & 0.461 & & 0.330 & 0.570 & & 1.362 & 0.250 & \\
\hline \multirow{4}{*}{ Total } & degraded vs moderate & 0.245 & 0.623 & 0.902 & 0.348 & & 1.982 & 0.168 & & 1.290 & 0.263 & \\
\hline & degraded vs good & 0.001 & 0.982 & 0.881 & 0.354 & & 3.815 & 0.059 & $*$ & 4.053 & 0.051 & $*$ \\
\hline & moderate vs good & 0.273 & 0.604 & 0.008 & 0.927 & & 0.083 & 0.775 & & 0.424 & 0.519 & \\
\hline & degraded vs others & 0.096 & 0.758 & 0.960 & 0.333 & & 3.349 & 0.076 & * & 2.819 & 0.101 & \\
\hline
\end{tabular}

$*$ significance at $10 \%$ level,$* *$ significance at $5 \%$ level

Finally, we analyze if the scores for asset values are correlated to the trend of natural resource quality. 错误!未 找到引用源。 shows the average asset value scores for the trend of natural resource quality. For crop land and rangeland we only find for financial assets that lower scores correspond to the 'degrading' trend, for all other asset values the 'decreasing' category has the highest or second to the highest score. For forest the natural and human asset value scores were lowest for 'decreasing'. For water we found that lowest asset scores for physical, financial, natural, social, and total were given for the 'decreasing' categories. Highest scores for crop land that corresponded to the 'improving' trend were found for the physical, financial and total asset values. For rangeland only physical assets had the highest score for 'improving'. For forest we found highest scores for 'improving' for physical, financial, human and total; for water this holds for the assets financial, natural and social.

Table 9. Asset values scores by natural resources and trend of land quality

\begin{tabular}{llrrrrrrrr}
\hline & \multicolumn{1}{c}{ Crop land } & \multicolumn{3}{c}{ Rangeland } & \multicolumn{2}{l}{ Forest } & \multicolumn{3}{c}{ Water } \\
\hline \multirow{3}{*}{ Physical } & mean & sdev & Mean & sdev & mean & sdev & mean & sdev \\
& improving & 5.57 & 2.30 & 5.33 & 2.55 & 5.69 & 2.81 & 4.89 & 1.90 \\
& stable & 4.52 & 2.66 & 4.36 & 2.73 & 3.17 & 2.93 & 5.11 & 3.01 \\
& decreasing & 5.44 & 2.83 & 5.17 & 2.64 & 4.94 & 2.29 & 4.83 & 2.66 \\
Financial & improving & 6.43 & 2.23 & 5.11 & 1.76 & 4.92 & 2.75 & 4.56 & 2.30 \\
& stable & 4.73 & 2.30 & 5.55 & 2.42 & 4.00 & 1.67 & 5.39 & 2.17 \\
& decreasing & 3.67 & 1.32 & 4.11 & 2.49 & 4.67 & 2.30 & 4.08 & 2.54 \\
\multirow{3}{*}{ Human } & improving & 5.00 & 2.77 & 4.11 & 2.03 & 6.23 & 2.49 & 5.00 & 3.16 \\
& stable & 4.88 & 2.32 & 4.64 & 2.01 & 3.83 & 0.75 & 4.94 & 1.86 \\
& decreasing & 5.67 & 2.55 & 5.78 & 2.16 & 4.22 & 2.24 & 5.25 & 2.60 \\
& improving & 6.57 & 1.51 & 6.11 & 1.05 & 6.69 & 1.75 & 6.78 & 1.20 \\
& stable & 6.67 & 1.24 & 7.09 & 1.45 & 6.83 & 1.47 & 6.78 & 1.40 \\
& decreasing & 6.67 & 1.87 & 6.50 & 1.58 & 6.61 & 1.24 & 6.25 & 1.60 \\
& improving & 6.71 & 2.14 & 6.44 & 1.94 & 6.54 & 1.71 & 6.78 & 1.99 \\
& stable & 6.30 & 1.83 & 6.27 & 2.00 & 6.83 & 1.94 & 6.61 & 1.85 \\
Total & decreasing & 7.44 & 1.59 & 6.56 & 1.92 & 6.33 & 2.06 & 5.92 & 2.11 \\
& improving & 30.29 & 8.12 & 27.11 & 5.53 & 30.08 & 8.02 & 28.00 & 7.21 \\
& stable & 27.09 & 7.25 & 27.91 & 7.42 & 24.67 & 6.92 & 28.83 & 7.37
\end{tabular}


28.11

8.10

26.78

7.46

26.33

8.07

错误!未找到引用源。 reports on the statistical significance of differences that were found for asset value scores by trend category. We compare, by asset and natural resource, the scores for a) 'improving' against 'stable', b) 'improving' against 'decreasing', c) 'stable' against 'decreasing' and d) 'decreasing' against the average of all other scores. For crop land we find significant differences for financial assets for the comparison between 'improving' against 'stable', 'improving' against 'decreasing' and 'decreasing' against the average of all other scores. As we discussed in the previous paragraph, the scores of values follows the expected high scores for 'improving' and lowest for 'decreasing' trends, with a score in between these extremes for 'stable'. For rangeland we found significant differences for the human asset when we compare 'improving' against 'decreasing' and 'decreasing' against the average of all other scores. Yet, the highest scores were given for 'decreasing' and lowest scores for 'improving'. Forest reported significant differences in scores for the physical asset when comparing the 'improving' against 'stable', whereby we remark that the score for 'improving' was almost twice as high as for 'stable'. Also for human asset we found significant differences between 'improving' against 'stable' and 'improving' against 'decreasing', with highest scores for the 'improving' category, lowest for 'stable' and with 'decreasing' in between these scores. For water we did not find any significance in the differences between the asset value scores.

Table 10. GLM-Anova results for asset value scores by asset, natural resource and trend of natural resource quality

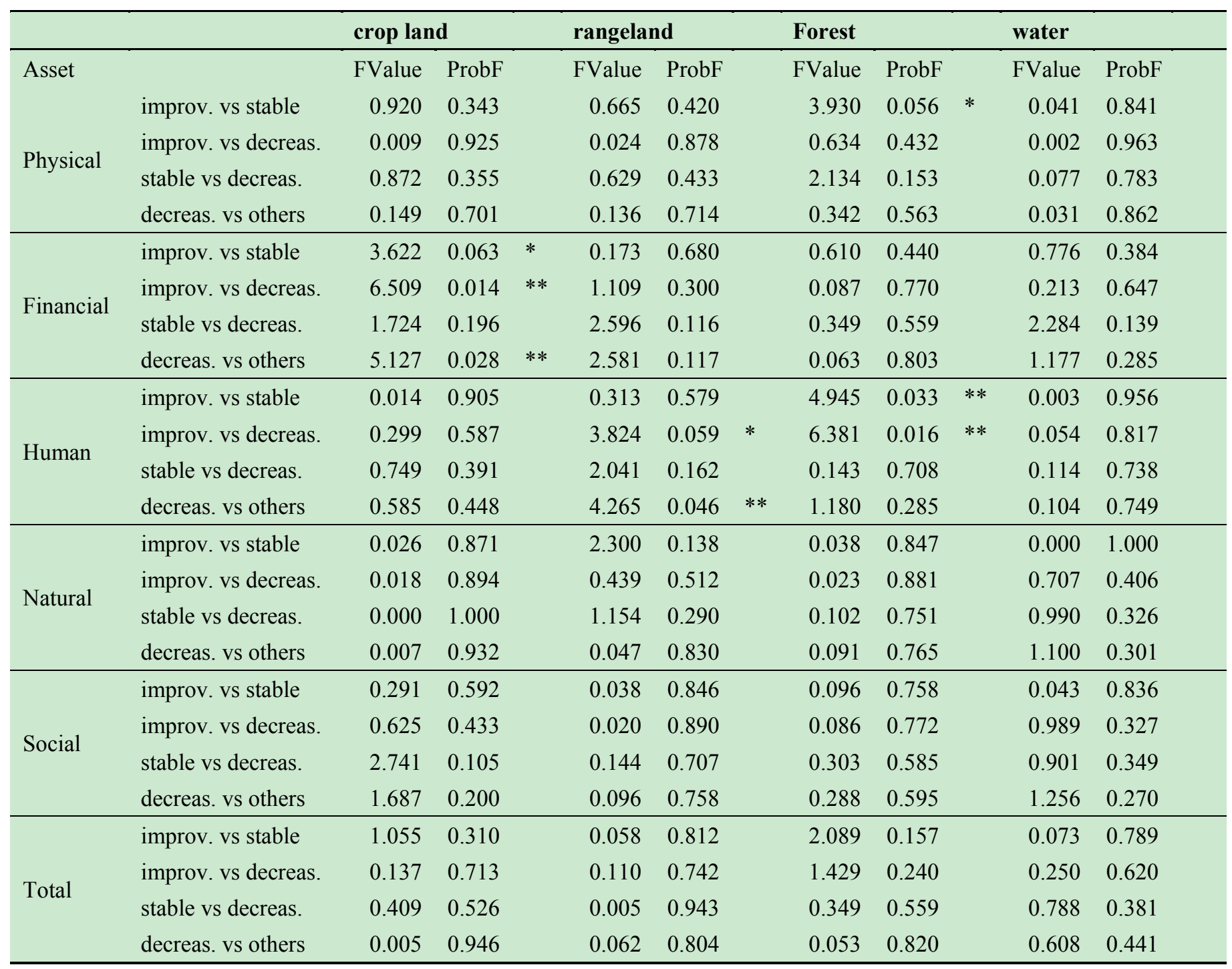

\footnotetext{
*significance at $10 \%$ level,$* *$ significance at $5 \%$ level
} 


\section{Conclusions}

Answering the question that is posed in our title, we have to conclude that asset values in general do not correlate straightforwardly and unequivocally with state and trend of natural resource quality. For our categorical asset value classes as well as for the continuous representation of scoring levels we did not find assuring relationships which indicate that asset values have a predictive power for natural resource quality. Hence we can state that our working hypothesis that relates poor farmers to a higher incidence of land degradation is proven to be incorrect. Obviously, adaptation to resource-conserving technologies, possibly supported by local institutions, is not related to farmers' endowments (Scherr, 2000).

For the state of forest we found some evidence of differences but these pointed to counterintuitive results of higher asset values that were related to 'degraded' classes. There might be a possibility that trend of natural resource quality for forests can be derived from asset value scores for physical and human.

The results refer to the well-known fact that land degradation is a complex process that is influenced by many factors, most of which are unknown or unobserved. This bias in the observed data makes it also difficult to establish a relationship that clearly measures the effect of an asset on the state and trend of land quality. Of course, the number of factors could be extended and each component of individual assets could be considered as an individual explanatory factor, yet, problems of overfitting and parameter identification, where multiple sets of parameters generate the same observations distribution, looms large.

The approach in a follow-up study could use various techniques (principal component analysis or kernel density regression) to select a limited number of location specific components of asset values that are related to the state and trend of natural resource quality. Possibly accompanied with randomized control trials where farmers are allowed to experiment with certain assets and the quality of the natural resource base is carefully monitored and quantified. The approach would strengthen the empirical basis of further research and hopefully be supportive in improving the decision makers' interventions.

\section{Acknowledgements}

This research was sponsored by the FAO-GEF-UNEP Land Degradation in Dryland Areas project. The authors thank Kees Traas (SOW-VU) for his constructive comments on an earlier draft.

\section{References}

ADB. (2014). Senegal Economic Outlook. African Development Bank Group. Retrieved from http://www.afdb.org/en/countries/west-africa/senegal/senegal-economic-outlook/

Barbier, E. B. (2000). The economic linkages between rural poverty and land degradation: some evidence from Africa. Agriculture, Ecosystems \& Environment, 82(1-3), 355-370. http://dx.doi.org/10.1016/S0167-8809(00)00237-1

Breshears, D. D., Whicker, J. J., Johansen, M. P., \& Pinder, J. E. (2003). Wind and water erosion and transport in semi-arid shrubland, grassland and forest ecosystems: quantifying dominance of horizontal wind-driven transport. Earth Surf. Process. Landforms, 28, 1189-1209. http://dx.doi.org/10.1002/esp.1034

Bunning, S., McDonagh, J., Rioux, J., \& Woodfine, A. (2001). Manual for Local Level Assessment of Land Degradation and Sustainable Land Management. Part 1. Planning and methodological approach, analysis and reporting. FAO, Rome, Italy.

Carney, D. (1998). Sustainable rural livelihoods: what contribution can we make? Papers presented at the Department for International Development's Natural Resources Advisers' Conference, July 1998. pp. vii + $213 \mathrm{pp}$.

Chambers, R., \& Conway, G. R. (1992). Sustainable Rural Livelihoods: Practical Concepts for the 21st Century, Discussion Paper 296. Institute of Development Studies, Brighton, UK.

Chen, H., Zhu, T., Krott, M., Calvo, J. F., Ganesh, S. P., \& Makoto, I. (2013). Measurement and evaluation of livelihood assets in sustainable forest commons governance. Land Use Policy, 30(1), 908-914. http://dx.doi.org/10.1016/j.landusepol.2012.06.009

DHS. (2013). Continuous Demographic and Health Survey in Senegal 2012-2013. Final Report Year 1. Agence Nationale de la Statistique et de la Démographie (ANSD), Dakar, Senegal. MEASURE DHS ICF International Calverton, Maryland, USA.

Firew, A. T. (2014). Land management in the north-western highlands of Ethiopia: adoption and impact. PhD 
thesis: "Wageningen University.

Gamvroudisa, C., Nikolaidisa, N. P., Tzorakib, O., Papadoulakisc, V., \& Karalemasc, N. (2015). Water and sediment transport modeling of a large temporary river basin in Greece. Science of The Total Environment, 508(1), 354-365. http://dx.doi.org/10.1016/j.scitotenv.2014.12.005

Hairsine, P. B., \& Rose, C. W. (1992). Modeling water erosion due to overland flow using physical principles: 2. Rill flow, Water Resour. Res., 28(1), 245-250. http://dx.doi.org/10.1029/91WR02381

Hopkins, C. G., \& Kenneth, D. (1978). Applicability of chi-square to $2 \times 2$ contingency tables with small expected cell frequencies. Psychological Bulletin, 85(1), 163-167. http://dx.doi.org/10.1037/0033-2909.85.1.163

IFDC. (2006). Abuja Declaration on Fertilizer for an African Green Revolution. Africa Fertilizer Summit, African Union Special Summit of the Heads of State and Government. - Abuja, Nigeria, 13 June 2006.

Katerberg, L., Khan, A., \& Ruddick, S. (2012). Evaluating value chain impact using a sustainable livelihoods approach: A case study on horticulture in Afghanistan. Enterprise Development and Microfinance, 22(3).

McDonagh, J., Bunning, S., McGarry, D., Liniger, H., Rioux, J., Nachtergaele, F., \& Biancalani, R. (2010). Field Manual for Local Level Land Degradation Assessment in Drylands LADA-L Part 1: Methodological Approach, Planning and Analysis. Part 2:Local Assessment: Tools and Methods for Fieldwork. FAO, Rome.

Nearing, M. A., \& Hairsine, P. B. (2011). The Future of Soil Erosion Modelling in: R.P.C. Morgan and M.A. Nearing eds. Handbook of Erosion Modelling. Blackwell Publishing Ltd., 390-397.

Nkonya, E., \& Anderson, W. (2015). Exploiting provisions of land economic productivity without degrading its natural capital. Journal of Arid Environments, 112(Part A), 33-43.

Pender, J., Nkonya, E., Jagger, P., Sserunkuuma, D., \& Ssali, H. (2004), Strategies to increase agricultural productivity and reduce land degradation: evidence from Uganda. Agricultural Economics, 31, $181-195$. http://dx.doi.org/10.1111/j.1574-0862.2004.tb00256.x

Pingali, P., Schneider, K., \& Zurek, M. (2014). Poverty, Agriculture and the Environment: The Case of Sub-Saharan Africa. In J. von Braun, \& F. W. Gatzweiler (Eds.), Marginality: Addressing the Nexus of Poverty, Exclusion and Ecology, Chapter 10, 151-168. http://dx.doi.org/10.1007/978-94-007-7061-4_10

Preacher, K. J. (2001). Calculation for the chi-square test: An interactive calculation tool for chi-square tests of goodness of fit and independence [Computer software]. Retrieved from http://quantpsy.org

Quine, T. A., Govers, G., Walling, D. E., Zhang, X., Desmet, P. J. J., Zhang, Y., \& Vandaele, K. (1997). Erosion processes and landform evolution on agricultural land - new perspectives from caesium-137 measurements and topographic-based erosion modelling. Earth Surf. Process. Landforms, 22, $799-816$. http://dx.doi.org/10.1002/(SICI)1096-9837(199709)22:9<799::AID-ESP765>3.0.CO;2-R

Scherr, S. J. (2000). A downward spiral? Research evidence on the relationship between poverty and natural resource degradation. Food Policy, 25(4), 479-498. http://dx.doi.org/10.1016/S0306-9192(00)00022-1

Scoones, I. (1998). Sustainable Rural Livelihoods: A Framework for Analysis. Working Paper, 72, Institute for Development Studies, Brighton, UK.

Sonneveld, B. G. J. S., Keyzer, M. A., Zikhali, P., \& Merbis, M. (2010). National Land Degradation Assessment Senegal and Review of global socio-economic parameters in the LADA data base. Land Degradation Assessment (LADA) project. SOW-VU, Amsterdam. Report for the FAO.

Tittonell, P., \& Giller, K. E. (2013). When yield gaps are poverty traps: The paradigm of ecological intensification in African smallholder agriculture. Field Crops Research, 143(1), 76-90. http://dx.doi.org/10.1016/j.fcr.2012.10.007

Vu, Q. M., Le, Q. B., Frossard, E., \& Vlek, P. L. G. (2014). Socio-economic and biophysical determinants of land degradation in Vietnam: An integrated causal analysis at the national level. Land Use Policy 36, 605617. http://dx.doi.org/10.1016/j.landusepol.2013.10.012

\section{Notes}

Note 1. This study tested the consistency of expert judgments by a cross-comparison of mapping units with identical characteristics for annual rainfall, soil suitability, slope, population density and livestock density. The study concluded that experts had a high consistency in their judgment and gave reliable assessment on the degree 
of land degradation.

Note 2. A GAA is defined as a watershed or an area of several 100 square kms that is representative for the country's prevailing land uses, sustainable land management activities and type and extent of land degradation.

\section{Appendixes}

Table A 1. Frequency distribution of asset value classes and state of land quality by asset and natural resource

\begin{tabular}{|c|c|c|c|c|c|c|}
\hline Asset & Asset class & Land quality & Rainfed & Rangeland & Forest & Water \\
\hline \multirow{9}{*}{ Physical } & \multirow{3}{*}{ Low } & Good & 7 & 10 & 11 & 11 \\
\hline & & Moderate & 5 & 4 & 2 & 2 \\
\hline & & Low & 4 & 1 & 0 & 1 \\
\hline & \multirow{3}{*}{ Moderate } & Good & 11 & 11 & 8 & 14 \\
\hline & & Moderate & 7 & 8 & 6 & 6 \\
\hline & & Low & 9 & 2 & 4 & 4 \\
\hline & \multirow{3}{*}{ High } & Good & 4 & 4 & 3 & 4 \\
\hline & & Moderate & 1 & 2 & 0 & 0 \\
\hline & & Low & 1 & & 3 & 2 \\
\hline \multirow{9}{*}{ Financial } & \multirow{3}{*}{ Low } & Good & 7 & 6 & 9 & 10 \\
\hline & & Moderate & 6 & 5 & 1 & 3 \\
\hline & & Low & 3 & 2 & 2 & 2 \\
\hline & \multirow{3}{*}{ Moderate } & Good & 13 & 15 & 12 & 15 \\
\hline & & Moderate & 6 & 9 & 6 & 5 \\
\hline & & Low & 8 & 0 & 3 & 4 \\
\hline & \multirow{3}{*}{ High } & Good & 2 & 4 & 1 & 4 \\
\hline & & Moderate & 1 & 0 & 1 & 0 \\
\hline & & Low & 3 & 1 & 2 & 1 \\
\hline \multirow{9}{*}{ Natural } & \multirow{3}{*}{ Low } & Good & 0 & 0 & 0 & 0 \\
\hline & & Moderate & 0 & 0 & 0 & 0 \\
\hline & & Low & 0 & 0 & 0 & 0 \\
\hline & \multirow{3}{*}{ moderate } & Good & 13 & 18 & 16 & 21 \\
\hline & & Moderate & 9 & 9 & 7 & 5 \\
\hline & & Low & 12 & 2 & 2 & 5 \\
\hline & \multirow{3}{*}{ high } & Good & 9 & 7 & 6 & 8 \\
\hline & & Moderate & 4 & 5 & 1 & 3 \\
\hline & & Low & 2 & 1 & 5 & 2 \\
\hline \multirow{8}{*}{ Human } & \multirow{3}{*}{ low } & Good & 6 & 9 & 10 & 10 \\
\hline & & Moderate & 4 & 3 & 2 & 2 \\
\hline & & Low & 4 & & 1 & 1 \\
\hline & \multirow{3}{*}{ moderate } & Good & 12 & 15 & 8 & 15 \\
\hline & & Moderate & 6 & 7 & 5 & 4 \\
\hline & & Low & 8 & 1 & 4 & 4 \\
\hline & \multirow{2}{*}{ high } & Good & 4 & 1 & 4 & 4 \\
\hline & & Moderate & 3 & 4 & 1 & 2 \\
\hline
\end{tabular}




\begin{tabular}{|c|c|c|c|c|c|c|}
\hline & & Low & 2 & 2 & 2 & 2 \\
\hline & & Good & 2 & 2 & 0 & 2 \\
\hline & low & Moderate & 0 & 0 & 0 & 0 \\
\hline & & Low & 0 & 0 & 1 & 0 \\
\hline & & Good & 12 & 15 & 17 & 21 \\
\hline \multirow[t]{5}{*}{ Social } & moderate & Moderate & 9 & 10 & 6 & 5 \\
\hline & & Low & 10 & 1 & 1 & 2 \\
\hline & & Good & 8 & 8 & 5 & 6 \\
\hline & high & Moderate & 4 & 4 & 2 & 3 \\
\hline & & Low & 4 & 2 & 5 & 5 \\
\hline
\end{tabular}

Table A 2. Frequency distribution of asset value classes and trend of land quality by asset and natural resource

\begin{tabular}{|c|c|c|c|c|c|c|}
\hline & Asset Value & Trend & Rainfed & Rangeland & Forest & Water \\
\hline \multirow{12}{*}{ Physical } & \multirow{4}{*}{ low } & improving & 1 & 3 & 3 & 2 \\
\hline & & stable & 3 & 4 & 4 & 4 \\
\hline & & decreasing & 9 & 6 & 6 & 4 \\
\hline & & rapidly decreasing & 1 & 0 & 0 & 1 \\
\hline & \multirow{4}{*}{ moderate } & improving & 5 & 5 & 7 & 7 \\
\hline & & stable & 4 & 6 & 2 & 11 \\
\hline & & decreasing & 14 & 9 & 10 & 4 \\
\hline & & rapidly decreasing & 1 & 0 & 0 & 1 \\
\hline & \multirow{4}{*}{ high } & improving & 1 & 1 & 3 & 0 \\
\hline & & stable & 2 & 1 & 0 & 3 \\
\hline & & decreasing & 1 & 3 & 2 & 2 \\
\hline & & rapidly decreasing & 0 & 0 & 0 & 0 \\
\hline \multirow{12}{*}{ Financial } & \multirow{4}{*}{ low } & improving & 1 & 2 & 5 & 4 \\
\hline & & stable & 3 & 3 & 3 & 3 \\
\hline & & decreasing & 8 & 8 & 5 & 5 \\
\hline & & rapidly decreasing & 1 & 0 & 0 & 1 \\
\hline & \multirow{4}{*}{ moderate } & improving & 4 & 7 & 6 & 5 \\
\hline & & stable & 5 & 5 & 3 & 11 \\
\hline & & decreasing & 13 & 8 & 11 & 4 \\
\hline & & rapidly decreasing & 1 & 0 & 0 & 1 \\
\hline & \multirow{4}{*}{ high } & improving & 2 & 0 & 2 & 0 \\
\hline & & stable & 1 & 3 & 0 & 4 \\
\hline & & decreasing & 3 & 2 & 2 & 1 \\
\hline & & rapidly decreasing & 0 & 0 & 0 & 0 \\
\hline \multirow{7}{*}{ Natural } & \multirow{4}{*}{ low } & improving & 0 & 0 & 0 & 0 \\
\hline & & stable & 0 & 0 & 0 & 0 \\
\hline & & decreasing & 0 & 0 & 0 & 0 \\
\hline & & rapidly decreasing & 0 & 0 & 0 & 0 \\
\hline & \multirow{3}{*}{ moderate } & improving & 5 & 8 & 9 & 6 \\
\hline & & stable & 6 & 6 & 4 & 11 \\
\hline & & decreasing & 17 & 12 & 12 & 9 \\
\hline
\end{tabular}




\begin{tabular}{|c|c|c|c|c|c|c|}
\hline & \multirow{5}{*}{ high } & rapidly decreasing & 1 & 0 & 0 & 1 \\
\hline & & improving & 2 & 1 & 4 & 3 \\
\hline & & stable & 3 & 5 & 2 & 7 \\
\hline & & decreasing & 7 & 6 & 6 & 1 \\
\hline & & rapidly decreasing & 1 & 0 & 0 & 1 \\
\hline \multirow{12}{*}{ Human } & \multirow{4}{*}{ low } & improving & 3 & 4 & 3 & 3 \\
\hline & & stable & 2 & 4 & 2 & 4 \\
\hline & & decreasing & 7 & 2 & 7 & 3 \\
\hline & & rapidly decreasing & 0 & 0 & 0 & 0 \\
\hline & \multirow{4}{*}{ moderate } & improving & 2 & 4 & 5 & 3 \\
\hline & & stable & 6 & 5 & 4 & 12 \\
\hline & & decreasing & 13 & 12 & 9 & 4 \\
\hline & & rapidly decreasing & 2 & 0 & 0 & 2 \\
\hline & \multirow{4}{*}{ high } & improving & 2 & 1 & 5 & 3 \\
\hline & & stable & 1 & 2 & 0 & 2 \\
\hline & & decreasing & 4 & 4 & 2 & 3 \\
\hline & & rapidly decreasing & 0 & 0 & 0 & 0 \\
\hline \multirow{12}{*}{ Social } & \multirow{4}{*}{ low } & improving & 0 & 0 & 0 & 0 \\
\hline & & stable & 2 & 1 & 0 & 1 \\
\hline & & decreasing & 0 & 1 & 1 & 1 \\
\hline & & rapidly decreasing & 0 & 0 & 0 & 0 \\
\hline & \multirow{4}{*}{ moderate } & improving & 5 & 7 & 10 & 7 \\
\hline & & stable & 5 & 6 & 3 & 11 \\
\hline & & decreasing & 18 & 11 & 11 & 7 \\
\hline & & rapidly decreasing & 0 & 0 & 0 & 0 \\
\hline & \multirow{4}{*}{ high } & improving & 2 & 2 & 3 & 2 \\
\hline & & stable & 2 & 4 & 3 & 6 \\
\hline & & decreasing & 6 & 6 & 6 & 2 \\
\hline & & rapidly decreasing & 2 & 0 & 0 & 2 \\
\hline
\end{tabular}

\section{Copyrights}

Copyright for this article is retained by the author(s), with first publication rights granted to the journal.

This is an open-access article distributed under the terms and conditions of the Creative Commons Attribution license (http://creativecommons.org/licenses/by/3.0/). 